
JURNAL ABDIMAS
P-ISSN 0000-0000, E-ISSN 0000-0000

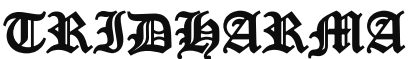
Jurnal ABDIMAS Vol. 1,No.1, Agustus 2019, Hal (27-40)

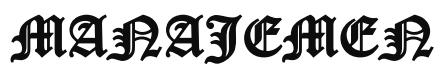
@Prodi Manajemen Fakultas Ekonomi Universitas Pamulang
Email: abdimasjurnal.unpam@gmail.com Telp: (021) 741-2566

\title{
REORIENTASI PERAN KARANG TARUNA : MENGEMBANGKAN MANAJEMEN ORGANISASI YANG SELARAS DENGAN KONTEKS PEMBANGUNAN DAERAH
}

\author{
Arif Siaha Widodo, Dedek Kumara, Surti Wardani \\ Dosen Fakultas Ekonomi Universitas Pamulang \\ Email: dosen01725@unpam.ac.id
}

\begin{abstract}
ABSTRAK
Pengabdian ini berjudul Reorientasi Peran Karang Taruna : Mengembangkan Manajemen Organisasi Yang Selaras Dengan Konteks Pembangunan Daerah.

Tujuan pengabdian ini adalah untukuntuk mengembangkan dan membangkitkan kembali kegiatan kepemudaan melalui wadah organisasi yang sudah lama ada, yaitu Karang Taruna, memberikan motivasi serta kepercayaan diri segenap pengurus dan anggota Karang Taruna Kelurahan Pondok Benda, Pamulang. Secara rinci, tujuan kegiatan ini diantaranya untuk mengetahui dasardasar manajemen organisasi,memahami dasar-dasar organisasi dengan struktur dan desain organisasi yang baik,mengembangkan organisasi karang taruna menjadi organisasi yang bermanfaat, mengetahui apa saja pendukung dan penghambat organisasi kepemudaan.

Metode pelaksanaan pengabdian ini dilakukan dalam beberapa kegiatan yaitu dengan melibatkan banyak pihak selain dari pihak Karang Taruna juga melibatkan pihak dari kelurahan mulai dari Lurah, dan staff kelurahan di kelurahan Pondok Benda, Kecamatan Pamulang, Kota Tangerang Selatan, Propinsi Banten. Berhubung kegiatan seminar ini juga bertepatan agenda rutin kegiatan Karang Taruna di Kelurahan Pondok Benda, maka pelaksanaan kegiatan ini juga melibatkan panitia dari Karang Taruna, Kegiatan ini juga akan menampilkan berbagai kegiatan lain yang di selenggarakan oleh pihak Karang Taruna. Dalam proses kegiatan kali ini metodenya berupa seminar dimana narasumber akan berinteraksi aktif dengan audience, jadi lebih bersifat sharing interaktif, agar semua yang terlibat bisa merasakan manfaatnya langsung dan mendapatkan wawasan yang lebih mendalam tentang bagaimana mengelola organisasi yang baik, sehingga pada akhirnya nanti dapat menerapkan dalam kegiatan organisasinya.

Kesimpulan dari pengabdian ini adalahsecara umum kegiatan pengabdian kepada masyarakat dapat terlaksana dengan baik dan mendapat sambutan dan dukungan dari pihak Kelurahan Karang Benda dari segi tempat, sarana prasarana dan akomodasi, serta antusias para peserta yaitu pengurus dan anggota Karang Taruna Kelurahan Pondok Benda sehingga dapat terciptanya kesadaran akan pentingnya peran dan kontribusi Karang Taruna dalam memajukan kehidupan masyarakat terutama di lingkungan masyarakat Kelurahan Pondok Benda.
\end{abstract}




\section{JURNAL ABDIMAS

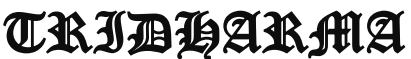

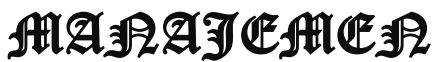

P-ISSN 0000-0000, E-ISSN 0000-0000

Jurnal ABDIMAS Vol. 1,No.1, Agustus 2019, Hal (27-40)

@Prodi Manajemen Fakultas Ekonomi Universitas Pamulang

Email: abdimasjurnal.unpam@gmail.com Telp: (021) 741-2566

\title{
Kata Kunci:Karang Taruna, Manajemen Organisasi, Pembangunan Daerah
}

\begin{abstract}
ABSTRAC
This service is titled the Reorientation of Youth Organizations: Developing Organizational Management in Accordance with the Regional Development Context.

The purpose of this service is to develop and revive youth activities through a long-standing organization, Karang Taruna, to provide motivation and selfconfidence to the entire board and members of the Karang Taruna Village, Pondok Benda, Pamulang.

In detail, the purpose of this activity is to find out the fundamentals of organizational management, understand the fundamentals of the organization with good organizational structure and design, develop youth organizations into useful organizations, find out what are the supporters and obstacles of youth organizations.

The method of implementing this service was carried out in several activities namely by involving many parties other than from the Youth Organization and also involving parties from the kelurahan starting from the Village Head, and village staff in Pondok Benda, Pamulang District, South Tangerang City, Banten Province. Since this seminar also coincided with the routine agenda of the Youth Organization activities in the Pondok Benda Subdistrict, the implementation of this activity also involved a committee from the Youth Organization, this activity will also feature various other activities organized by the Youth Organization. In this activity process the method is in the form of a seminar where the resource person will interact actively with the audience, so it is more interactive sharing, so that all involved can experience the benefits directly and get deeper insights on how to manage a good organization, so that eventually organizational activities.

The conclusion of this service is that in general the community service activities can be carried out well and receive remarks and support from the Karang Benda Village in terms of places, facilities and accommodations, and enthusiasm of the participants, namely the Karang Taruna Village Management and members so that they can be created awareness of the importance of the role and contribution of Youth Organization in advancing people's lives, especially in the community of Pondok Benda Village.
\end{abstract}

\section{Keywords :Youth Organization, Organizational Management, Regional Development.}




\section{JURNAL ABDIMAS

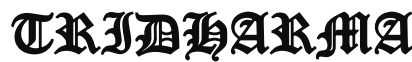

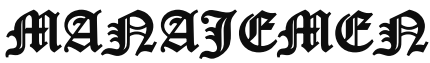

P-ISSN 0000-0000 , E-ISSN 0000-0000

Jurnal ABDIMAS Vol. 1,No.1, Agustus 2019, Hal (27-40)

@Prodi Manajemen Fakultas Ekonomi Universitas Pamulang

Email: abdimasjurnal.unpam@gmail.com Telp: (021) 741-2566

\section{PENDAHULUAN}

Pada umumnya generasi muda adalah generasi penerus bangsa yang harus dibina, dilatih, dan diarahkan ke hal-hal yang positif agar memberikan kesejahteraan sosial dilingkungan masyarakat. Anak muda sebagai aktor dari proses perubahan lingkungan makro sering dilupakan bahwa pada umumnya perubahan bangsa ini sebagian besar dilakukan oleh anak muda. Pemuda juga yang menegaskan cita-cita akan berdirinya Negara Indonesia. Oleh karena itu, dalam membangun bangsa ini diperlukan wadah organisasi sosial kepemudaan seperti Karang Taruna agar pemuda terus tumbuh dan berkembang atas dasar kesadaran dan tanggung jawab sosial. Namun umumnya masyarakat selalu berpendapat bahwa Karang Taruna hanya muncul dan aktif hanya pada saat Moment Peringatan 17 Agustus dan yang disayangkannya image atau citra ini pun melekat kuat pada persepsi pemuda-pemudi di Indonesia di era saat ini. Namun semua persepsi itu salah, sebenarnya Karang Taruna adalah salah satu Organisasi Kepemudaan yang ada di bawah binaan dari Kementrian Sosial yang fokus sasaran utamanya adalah meningkatkan Kesejahteraan Sosial Masyarakat.

Berdasarkan Permensos 83/HUK/2005 tentang pedoman dasar Karang Taruna maka tugas pokok dan fungsi Karang Taruna adalah bekerjasama dengan pihak pemerintah terkait dan komponen masyarakat lainnya untuk mengatasi berbagai masalah kesejahteraan sosial maupun pengembangan potensi yang dihadapi generasi muda di lingkungannya. Secara kedudukan lembaga Karang Taruna terdapat di beberapa tingkat institusi yakni tingkat Kelurahan, Kecamatan dan Kota.

Meninjau Karang Taruna Kelurahan Pondok Benda sebagai organisasi kepemudaan yang berkontribusi untuk mewujudkan solidaritas pemuda, masyarakat secara umum, dan pembinaan generasi muda, sebagai pembinaan generasi muda Karang Taruna Kelurahan Pondok Benda tentu saja mempunyai program yang akan dilaksanakan dan akan melibatkan seluruh komponen dan potensi yang ada sebagai organisasi yang bergerak di bidang pembangunan kesejahteraan sosial.Karang Taruna Kelurahan Pondok Benda sudah terbentuk atas Perintah Karang Taruna Kecamatan Pamulang sejak tahun 2004, permasalahannya kini Karang Taruna Kelurahan Pondok Benda sudah berganti pimpinan dan penyegaran anggotanya. Banyak anggota Karang Taruna Kelurahan Pondok Benda berpartisipasi menjadi anggota Karang Taruna dari setiap perwakilan RW dan RT, namun kurang paham mengenai organisasi kepemudaan. Melihat permasalahan tersebut maka dari itu kami selaku tim dosen dari Program Studi Manajemen Fakultas Ekonomi akan mengadakan pengabdian masyarakat berupa seminar di Karang Taruna Pondok Benda dengan judul "Reorientasi Peran Karang Taruna: Mengembangkan Manajemen Organisasi yang Selaras dengan Konteks Pembangunan Daerah". 


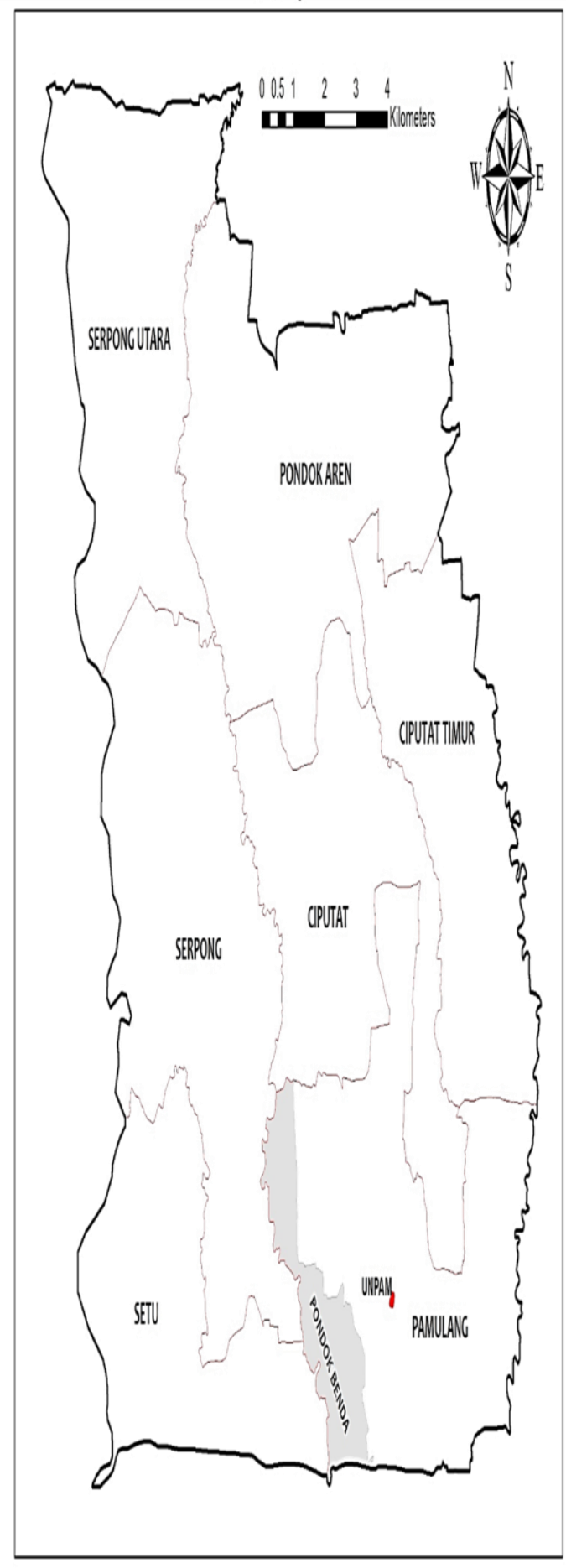

Gambar 1. Peta Lokasi Kegiatan Pengabdian Kepada Masyarakat Universitas Pamulang di Kelurahan Pondok Benda, Pamulang

\section{RUMUSAN MASALAH}

1. Memberikan pemahaman tentang falsafah dan tujuan Karang Taruna.

2. Memberikan pemahaman tentang manajemen, organisasi, dan organisasi sosial.

3. Memberikan pemahaman tentang organisasi sosial dan organisasi sukarela.

4. Meningkatkan kemampuan setiap anggota Karang Taruna dalam berorganisasi sosial.

5. Meningkatkan kemampuan setiap anggota Karang Taruna dalam menanggapi isu-isu sosial dalam masyarakat sehingga dapat melahirkan solusi bagi masyarakat.

6. Meningkatkan kemampuan analisa kekuatan, kelemahan, tantangan, dan peluang yang dihadapi oleh Karang Taruna dalam usaha kesejahteraan sosial sebagai organisasi sosial.

\section{TUJUAN PELAKSANAAN}

Tujuan kegiatan pengabdian masyarakat ini adalah untuk mengembangkan dan membangkitkan kembali kegiatan kepemudaan melalui wadah organisasi yang sudah lama ada, yaitu Karang Taruna, memberikan motivasi serta kepercayaan diri 


\section{JURNAL ABDIMAS

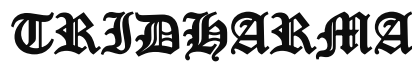

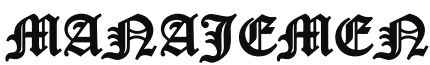

P-ISSN 0000-0000, E-ISSN 0000-0000

Jurnal ABDIMAS Vol. 1,No.1, Agustus 2019, Hal (27-40)

@Prodi Manajemen Fakultas Ekonomi Universitas Pamulang

Email: abdimasjurnal.unpam@gmail.com Telp: (021) 741-2566 segenap pengurus dan anggota Karang Taruna Kelurahan Pondok Benda, Pamulang. Secara rinci, tujuan kegiatan ini diantaranya untuk :

1. Mengetahui dasar-dasar manajemen organisasi.

2. Memahami Dasar-dasar organisasi dengan struktur dan desain organisasi yang baik.

3. Mengembangkan organisasi karang taruna menjadi organisasi yang bermanfaat.

4. Mengetahui apa saja pendukung dan penghambat organisasi kepemudaan.

\section{TINJAUAN PUSTAKA}

\section{Pengertian Manajemen}

Pengertian manajemen secara umum dapat disimpulkan dari beberapa definisi menurut para ahli. Hal ini karena ada banyak versi definisi manajemen. Misalnya saja manajemen menurut seorang ahli bernama Mary Parker Follet yang mendefinisikan manajemen sebagai seni merampungkan pekerjaan melalui orang lain. Dari definisi tersebut didapati bahwa seseorang yang bertugas sebagai manajer dapat mengarahkan dan mengatur orang lain guna mencapai tujuan organisasi. Di sisi lain, James A.F Stoner mendefinisikan manajemen sebagai proses pengorganisasian, perencanaan, dan penggunaan SDM supaya mencapai tujuan organisasi yang sudah ditetapkan. Secara umum, pengertian manajemen merupakan suatu seni dalam ilmu dan pengorganisasian seperti menyusun perencanaan, membangun organisasi dan pengorganisasiannya, pergerakan, serta pengendalian atau pengawasan. Bisa juga diartikan bahwa manajemen merupakan suatu ilmu pengetahuan yang sistematis agar dapat memahami mengapa dan bagaimana manusia saling bekerja sama agar dapat menghasilkan sesuatu yang bermanfaat bagi orang lain maupun golongan tertentu dan masyarakat luas. Secara etimologis, pengertian manajemen merupakan seni untuk melaksanakan dan mengatur. Manajemen ini juga dilihat sebagai ilmu yang mengajarkan proses mendapatkan tujuan dalam organisasi, sebagai usaha bersama dengan beberapa orang dalam organisasi tersebut. Sehingga, ada orang yang merumuskan dan melaksanakan tindakan manajemen yang disebut dengan manajer.

\section{FUNGSI MANAJEMEN}

Pada dasarnya, fungsi manajemen dibagi menjadi tiga, yaitu:

1. Perencanaan (planning)

Pernecanaan adalah memikirkan apa yang akan dikerjakan dengan sumber yang dimiliki. Perencanaan dilakukan untuk menentukan tujuan perusahaan secara keseluruhan dan cara terbaik untuk memenuhi tujuan itu. Manajer mengevaluasi berbagai rencana alternatif sebelum mengambil tindakan dan kemudian melihat apakah rencana yang dipilih cocok dan dapat digunakan untuk memenuhi tujuan perusahaan. Perencanaan merupakan proses terpenting dari semua fungsi manajemen karena tanpa perencanaan, fungsi-fungsi lainnya tak dapat berjalan. 


\section{JURNAL ABDIMAS P-ISSN 0000-0000, E-ISSN 0000-0000

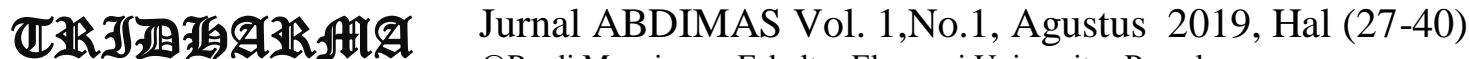

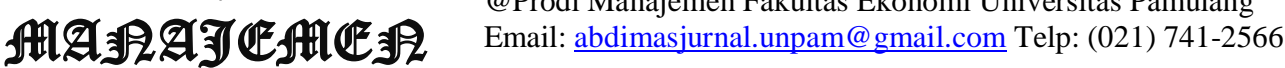

2. Pengorganisasian (organizing)

Pengorganisasian dilakukan dengan tujuan membagi suatu kegiatan besar menjadi kegiatankegiatan yang lebih kecil. Pengorganisasian mempermudah manajer dalam melakukan pengawasan dan menentukan orang yang dibutuhkan untuk melaksanakan tugas-tugas yang telah dibagi-bagi tersebut. Pengorganisasian dapat dilakukan dengan cara menentukan tugas apa yang harus dikerjakan, siapa yang harus mengerjakannya, bagaimana tugas-tugas tersebut dikelompokkan, siapa yang bertanggung jawab atas tugas tersebut, dan pada tingkatan mana keputusan harus diambil.

3. Pengarahan (directing)

Pengarahan adalah suatu tindakan untuk mengusahakan agar semua anggota kelompok berusaha agar dapat mencapai sasaran sesuai dengan perencanaan manajerial dan usaha.

\section{UNSUR-UNSUR MANAJEMEN}

Setiap perusahaan memiliki unsur-unsur untuk membentuk sistem manajerial yang baik. Unsur-unsur inilah yang disebut unsur manajemen. Jika salah satu diantaranya tidak sempurna atau tidak ada, maka akan berimbas dengan berkurangnya upaya untuk mencapai tujuan organisasi atau perusahaan. Unsurunsur tersebut diantaranya sebagai berikut.

Human (Manusia)

Dalam manajemen, faktor
manusia adalah yang paling

menentukan. Manusia yang membuat tujuan dan manusia pula yang melakukan proses untuk mencapai tujuan. Tanpa adanya manusia maka tidak ada proses kerja, sebab pada dasarnya manusia adalah makhluk kerja.

Money (Uang)

Uang merupakan salah satu unsur yang tidak dapat diabaikan.Uang merupakan alat tukar dan alat pengukur nilai. Besar-kecilnya hasil kegiatan dapat diukur dari jumlah uang yang beredar dalam perusahaan. Oleh karena itu uang merupakan alat (tools) yang penting untuk mencapai tujuan karena segala sesuatu harus diperhitungkan secara rasional. Hal ini akan berhubungan dengan berapa uang yang harus disediakan untuk membiayai gaji tenaga kerja, alat-alat yang dibutuhkan dan harus dibeli serta berapa hasil yang akan dicapai dari suatu organisasi.

Materials (Bahan)

Material terdiri dari bahan setengah jadi (raw material) dan bahan jadi. Dalam dunia usaha untuk mencapai hasil yang lebih baik, selain manusia yang ahli dalam bidangnya juga harus dapat menggunakan bahan/materi-materi sebagai salah satu sarana. Sebab materi dan manusia tidak dapat dipisahkan, tanpa materi tidak akan tercapai hasil yang dikehendaki. Machines (Mesin) Dalam kegiatan perusahaan, mesin sangat diperlukan. Penggunaan mesin akan membawa kemudahan atau menghasilkan keuntungan yang lebih besar serta menciptakan efisiensi kerja. 


\section{JURNAL ABDIMAS P-ISSN 0000-0000, E-ISSN 0000-0000

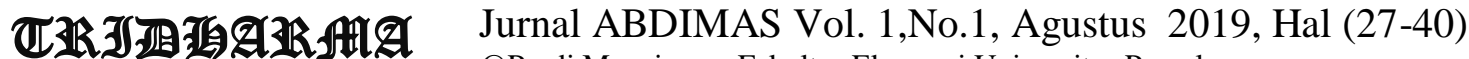

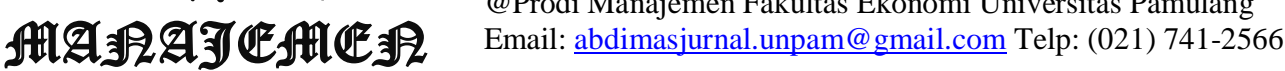

Methods (Metode)

Dalam pelaksanaan kerja diperlukan metode-metode kerja. Suatu tata cara kerja yang baik akan memperlancar jalannya pekerjaan. Sebuah metode dapat dinyatakan sebagai penetapan cara pelaksanaan kerja dengan memberikan berbagai pertimbangan-pertimbangan dari sasaran, fasilitas-fasilitas yang tersedia dan penggunaan waktu, serta uang dan kegiatan usaha. Perlu diingat meskipun metode baik, sedangkan orang yang melaksanakannya tidak mengerti atau tidak mempunyai pengalaman maka hasilnya tidak akan memuaskan. Dengan demikian, peranan utama dalam manajemen tetap manusia itu sendiri.

\section{Market (Pasar)}

Memasarkan produk tentu sangat penting sebab bila barang yang diproduksi tidak laku, maka proses produksi barang akan berhenti. Artinya, proses kerja tidak akan berlangsung. Oleh sebab itu, penguasaan pasar dalam arti menyebarkan hasil produksi merupakan faktor yang menentukan dalam perusahaan. Agar pasar dapat dikuasai maka kualitas dan harga barang harus sesuai dengan selera konsumen dan daya beli (kemampuan) konsumen.

Unsur- unsur manajemen menjadi hal mutlak dalam manajemen karena sebagai penentu arah perusahaan dalam melakukan kegiatan perusahaan. Selain itu, laporan keuangan juga menjadi penunjang dalam melaksanakan proses manajemen. Kini, Anda dapat membuat laporan keuangan dengan mudah menggunakan software akuntansi seperti Jurnal. Dengan menggunakan laporan keuangan dari Jurnal, Anda dapat lebih mudah melakukan kegiatan manajemen perusahaan hingga memudahkan dalam menentukan keputusan manajemen

\section{Pengertian Manajemen Sumber Daya Manusia}

Manajemen adalah ilmu dan seni yang megatur proses pemanfaatan sumber daya manusia dan sumbersumber daya lainya secara efektif dan efesien untuk mencapai suatu tujuan tertentu.

Manajemen sumber daya manusia merupakan bagian dari ilmu manajemen yang memfokuskan perhatianya pada pengaturan peranan sumber daya manusia dalam kegiatan organisasi. Hal ini dikarnakan dalam mencapai tujuanya, organisasi memerlukan sumber daya manusia sebagai pengeelola sistemnya, dan agar sistem ini berjalan, dalam pengelolaanya diperlukan beberapa aspek penting, seprti pelatihan, pengembangan, motivasi dan aspekaspek lainya. Hal ini yang menjadikan manajeman sumber daya manusia sebagai salah satu indikator penting pencapaian tujuan organisasi secara efektif dan efisien.( Mila Badriah, S.E.,M.M, 15: 2015).

Manusia selalu berperan aktif dan dominan dalam kegiatan organisasi karena manusia menjadi perencana, pelaku, dan penentu terwujudanya tujuan organisasi. Tujuan tidak mungkin terwujud tanpa 


\section{JURNAL ABDIMAS

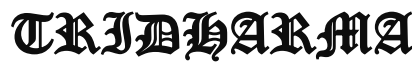 \\ AIA}

P-ISSN 0000-0000, E-ISSN 0000-0000

Jurnal ABDIMAS Vol. 1,No.1, Agustus 2019, Hal (27-40)

@Prodi Manajemen Fakultas Ekonomi Universitas Pamulang

Email: abdimasjurnal.unpam@gmail.com Telp: (021) 741-2566 peran aktif tanpa peran karyawan meskipun alat-alat yang dimiliki oleh perusahaan begitu canggih. Alat-alat canggih perusahaan tidak ada manfaatnya bagi perusahaan, jika peran aktif karyawan tidak di ikut sertakan. Mengatur karyawan merupakan hal yang sulit dan kompleks karena mereka mempunyai pikiran, perasaan, status, keinginan, dan latar belakang yang heterogen yang dibawa kedalam suatu organisasi. Karyawan tidak dapat di atur dan dikuasai sepenuhnya seperti mengatur mesin, moda, dan gedung.

Manajemen sumber daya manusia merupakan bagian dari manajemen. Oleh karna itu, teori-teori manajemen umum manjadi dasar pembahasaannya mengenai pengaturan peranaan manusia dalam menentukan tujuan yang optimal.

Pengaturan itu
$\begin{aligned} & \text { meliputi } \\ & \text { masalah perencanaan } \\ & \text { resources }\end{aligned}$
planning), pengorganisasian,pengarahaan,kompen asasi,pengintregrasian,pemeliharaan, kedisiplinan dan pemberhentian tenaga kerja untuk membantu terwujudnya tujuan perusahaan, karyawan, dan masyarakat. Pengertian manajeman sumber daya manusia menurut malayu S.P. Hasibuan ( 2005: 10 ) yang menyatakan bahwa : "manajeman sumber daya manusia adalah ilmu dan seni yang mengatur hubungan dan peranan tenaga kerja yang efektif dan efisien membantu terwujudnya tujuan perusahaan, karyawan, dan masyarakat".

\section{Motivasi}

Peran manusia yang tersedia di dalam perusahaan merupakan faktor utama untuk mencapai suatu tujuan perusahaan. Untuk menghendaki manusia agar sesuai dengan yang dikehendaki organisasi, maka harus dipahami motivasi manusia yang bekerja dalam organisasi tersebut, karena motivasi inilah yang menentukan perilaku orang-orang untuk bekerja.

Menurut Mangkunegara (2011:93) Motivasi adalah kondisi yang menggerakan pegawai agar mampu mencapai tujuan dan motifnya, sedangkan menurut Hadari Nawawi (2008: 351) motivasi adalah suatu kondisi yang mendorong atau menjadi sebab seseorang menjadi melakukan suatu perbuatan/kegiatan yang berlangsung secara sadar. Menurut Hasibuan (2011: 143) mengatakan bahwa motivasi adalah pemberian daya penggerak yang menciptakan kegairaan kerja seseorang, agar mereka mau bekerja sama, bekerja efektif dan terintegrasi dengan segala daya upaya untuk mencapai kepuasan. Robbin dalam Edy Sutrisno (2009: 117) menyatakan motivasi ialah "suatu kerelaan berusahaseoptimal mungkin dalam pencapaian tujuan organisasi yang dipengaruhi oleh kemampuan usaha memuaskan beberapakebutuhan individu". Sedangkan menurut M.Manulang dalam (2008: 194) yaitu motivasi merupakan pekerjaan yang dilakukan oleh seorang manajer memberikan inspirasi, semangat dan dorongan kepada orang lain, dalam hal ini karyawan untuk mengambil tindakan-tindakan. Pemberian dorongan ini bertujuan untuk 


\section{JURNAL ABDIMAS

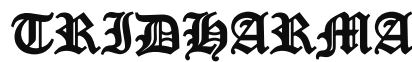

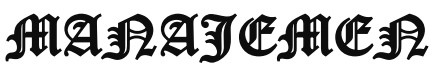

P-ISSN 0000-0000 , E-ISSN 0000-0000

Jurnal ABDIMAS Vol. 1,No.1, Agustus 2019, Hal (27-40)

@Prodi Manajemen Fakultas Ekonomi Universitas Pamulang

Email: abdimasjurnal.unpam@gmail.com Telp: (021) 741-2566 menggiatkan orangorang karyawan agar mereka bersemangat dan dapat mencapai hasil sebagaimana dikehendaki dari orang-orang tersebut.

Berdasarkan uraian tersebut, diperoleh kesimpulan bahwa motivasi merupakan unsur penggerak yang mendasari seseorang dalam melaksanakan pekerjaan. Produktivitas kerja karyawan didasari oleh bagaimana motivasi yang dimiliki karyawan tersebut untuk bekerja. Jika karyawan termotivasi untuk bekerja dengan baik, maka produktivitas kerja karyawan juga akan menjadi baik dan cenderung untuk meningkat.

\section{Organisasi}

Organisasi dapat diartikan
sebagai suatu kesatuan yang merupakan wadah atau sarana untuk mencapai berbagai tujuan atau sasaran organisasi memiliki banyak komponen yang melandasi diantaranya terdapat banyak orang, tata hubungan kerja, spesialis pekerjaan dan kesadaran rasional dari anggota sesuai dengan kemampuan dan spesialisasi mereka masing-masing. Berikut ini peneliti akan kemukakan beberapa pengertian organisasi menurut para ahli. Menurut Robbins (1994: 4) mengatakan, bahwa: "Organisasi adalah kesatuan sosial yang dikoordinasikan secara sadar, dengan sebuah batasan yang relatif dapat diidentifikasi, yang bekerja atas dasar yang relatif terus menerus untuk mencapai suatu tujuan bersama atau sekelompok tujuan."

$$
\text { Selanjutnya Hasibuan }
$$

(2011:120) memberikan pengertian organisasi sebagai berikut: Organisasi adalah suatu sistem perserikatan formal, berstruktur, dan terkoordinasi dari sekelompok orang yang bekerja sama dalam mencapai tujuan tertentu. Berdasarkan beberapa pengertian diatas dapat disimpulkan bahwa organisasi adalah suatu wadah yang terdiri dari unsur manusia yang saling bekerja 15 sama dan saling menguntungkan untuk kepentingan bersama dalam pencapaian tujuan organisasi.

Ciri-ciri organisasi dikemukakan Ferland yang dikutip oleh Handayaningrat (1985:3) sebagai berikut : 1 . Adanya suatu kelompok orang yang dapat dikenal 2. Adanya kegiatan yang berbeda-beda tetapi satu sama lain saling berkaitan (interdependent part) yang merupakan kesatuan usaha / kegiatan 3. Tiap-tiap anggota memberikan sumbangan usahanya / tenaganya 4. Adanya kewenangan, koordinasi dan pengawasan 5. Adanya suatu tujuan Organisasi selain dipandang sebagai wadah kegiatan orang juga dipandang sebagai proses, yaitu menyoroti interaksi diantara orang-orang yang menjadi anggota organisasi. Keberhasilan suatu organisasi ditentukan oleh kualitas sumberdaya manusia yang saling berinteraksi dan mengembangkan organisasi yang bersangkutan. Organisasi dalam meningkatkan Sumber Daya Manusia dalam rangka mengoptimalkan kinerja pegawai tidak terlepas dari pemberdayaan potensi yang ada.

\section{Karang Taruna}

Menurut Peraturan Menteri Sosial RI tahun 2010 Pasal 1 ayat 1 karang taruna adalah: Karang Taruna 


\section{JURNAL ABDIMAS

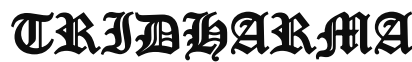

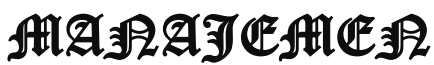

P-ISSN 0000-0000, E-ISSN 0000-0000

Jurnal ABDIMAS Vol. 1,No.1, Agustus 2019, Hal (27-40)

@Prodi Manajemen Fakultas Ekonomi Universitas Pamulang

Email: abdimasjurnal.unpam@gmail.com Telp: (021) 741-2566 adalah organisasi sosial kemasyarakatan sebagai wadah dan sarana pengembangan setiap anggota masyarakat yang tumbuh dan berkembang atas dasar kesadaran dan tanggung jawab sosial dari, oleh dan untuk masyarakat terutama generasi muda di wilayah desa/kelurahan terutama bergerak dibidang usaha kesejahteraan sosial.

Direktorat Bina Karang

Taruna (2005:1) menyebutkan bahwa:

a. Karang taruna adalah suatu organisasi sosial, perkumpulan sosial yang dibentuk oleh masyarakat yang berfungsi sebagai sarana partisipasi masyarakat dalam melaksanakan Usaha Kesejahteraan Sosial (UKS).

b. Sebagai wadah pengembangan generasi muda, karang taruna merupakan tempat diselenggarakannya berbagai upaya atau kegiatan untuk meningkatkan dan mengembangkan cipta, rasa, karsa, dan karya generasi muda dalam rangka pengembangan sumber daya manusia (SDM).

c. Karang taruna tumbuh dan berkembang atas dasar adanya kesadaran terhadap keadaan dan permasalahan di lingkungannya serta adanya tanggung jawab sosial untuk turut berusaha menanganinya. Kesadaran dan tanggung jawab sosial tersebut merupakan modal dasar tumbuh dan berkembangnya karang taruna.

d. Karang Taruna tumbuh dan berkembang dari generasi muda, diurus atau dikelola oleh generasi muda dan untuk kepentingan generasi muda dan masyarakat di wilayah desa/kelurahan atau komunitas adat sederajat. Karenanya setiap desa/kelurahan atau komunitas adat sederajat dapat menumbuhkan dan mengembangkan karang tarunanya sendiri.

e. Gerakannya di bidang usaha kesejahteraan sosial berarti bahwa semua upaya program dan kegiatan yang diselenggarakan karang taruna ditujukan guna mewujudkan kesejahteraan sosial masyarakat terutama generasi mudanya.

Taruna :

Landasan Hukum Karang

a. Undang-undang No. 32 tahun 2004 tentang pemerintah daerah tertanggal 15 Oktober 2004.

b. Peraturan Pemerintah No. 72 tentang Desa tertanggal 30 Desember 2005.

c. Peraturan Pemerintah No. 73 tentang Kelurahan tertanggal 30 Desember 2005.

d. Permensos RI Nomor 83/HUK/2005 tentang Pedoman Dasar Karang Taruna tertanggal 27 Juli 2005.

e. Permendagri RI Nomor 5 Tahun 2007 tentang Pedoman Penataan Lembaga tertanggal 5 Februari 2007.

Tujuan karang taruna menurut Direktorat Bina Karanag Taruna (2005:2) adalah:

a. Terwujudnya pertumbuhan dan perkembangan kesadaran tanggung jawab sosial setiap generasi muda warga karang taruna dalam mencegah, menangkal, menanggulangi dan mengantisipasi berbagai masalah sosial.

b. Terbentuknya jiwa dan semangat kejuangan generasi muda warga 


\section{JURNAL ABDIMAS

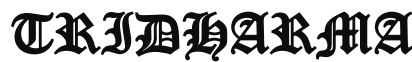 \\ AIA}

P-ISSN 0000-0000, E-ISSN 0000-0000

Jurnal ABDIMAS Vol. 1,No.1, Agustus 2019, Hal (27-40)

@Prodi Manajemen Fakultas Ekonomi Universitas Pamulang

Email: abdimasjurnal.unpam@gmail.com Telp: (021) 741-2566 karang taruna yang trampil dan berkepribadian serta berpengetahuan.

c. Tumbuhnya potensi dan kemampuan generasi muda dalam rangka mengembangkan keberdayaan warga karang taruna.

d. Termotivasinya setiap generasi muda karang taruna untuk mampu menjalin toleransi dan menjadi perekat persatuan dalam keberagaman kehidupan bermasyarakat, berbangsa dan bernegara.

e. Terjalinnya kerjasama antara generasi muda warga karang taruna dalam rangka mewujudkan taraf kesejahteraan sosial bagi masyarakat.

f. Terwujudnya kesejahteraan sosial yang semakin meningkat bagi generasi muda di desa/kelurahan atau komunitas adat sederajat yang memungkinkan pelaksanaan fungsi sosialnya sebagai manusia pembangunan yang mampu mengatasi masalah kesejahteraan sosial dilingkungannya.

g. Terwujudnya pembangunan kesejahteraan sosial generasi muda di desa/kelurahan atau komunitas adat sederajat yang dilaksanakan secara komprehensif, terpadu dan terarah serta berkesinambungan oleh karang taruna bersama pemerintah dan komponen masyarakat lainnya, secara bersama-sama dengan pemerintah dan komponen masyarakat lainnya untuk menanggulangi berbagai masalah kesejahteraan sosial terutama yang dihadapi generasi muda, baik yang bersifat preventif, rehabilitatif maupun pengembangan potensi generasi muda di lingkungannya.

\section{METODE PELAKSANAAN}

Dalam pelaksanaan kegiatan ini metode yang kita ambil adalah dengan melibatkan banyak pihak selain dari pihak Karang Taruna juga melibatkan pihak dari kelurahan mulai dari Lurah, dan staff kelurahan di kelurahan Pondok Benda, Kecamatan Pamulang, Kota Tangerang Selatan, Propinsi Banten. Berhubung kegiatan seminar ini juga bertepatan agenda rutin kegiatan Karang Taruna di Kelurahan Pondok Benda, maka pelaksanaan kegiatan ini juga melibatkan panitia dari Karang Taruna, Kegiatan ini juga akan menampilkan berbagai kegiatan lain yang di selenggarakan oleh pihak Karang Taruna. Dalam proses kegiatan kali ini metodenya berupa seminar dimana narasumber akan berinteraksi aktif dengan audience, jadi lebih bersifat sharing interaktif, agar semua yang terlibat bisa merasakan manfaatnya langsung dan mendapatkan wawasan yang lebih mendalam tentang bagaimana mengelola organisasi yang baik, sehingga pada akhirnya nanti dapat menerapkan dalam kegiatan organisasinya.

\section{HASIL DAN PEMBAHASAN}

Pelaksanaan

kegiatanpengabdian kepada masyarakat di Kelurahan Pondok Benda adalah sebagai berikut:Pelaksanaan seminar dilaksanakan di Kantor Kelurahan Pondok Benda lantai 3. Sebelum acara 


\section{JURNAL ABDIMAS P-ISSN 0000-0000, E-ISSN 0000-0000

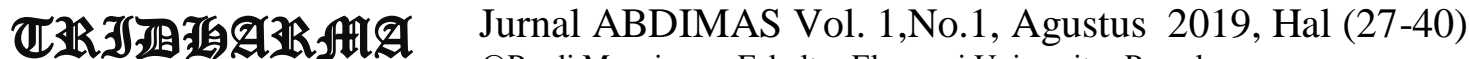 \\ @Prodi Manajemen Fakultas Ekonomi Universitas Pamulang \\ AIA}

dimulai tim dosen melakukan briefingdan temu sapa dengan Sekretaris Kelurahan, serta mempersiapkan peralatan yang dibutuhkan untuk menunjang kegiatan seminar.Setelah briefing tim dosen PKM selesai dilanjutkan dengan registrasi peserta seminar yang dimulai pukul 07.30 WIB. Jumlah peserta yang hadir sebanyak 47 peserta yang terdiri dari pengurus dan anggota Karang Taruna.Pembukaan acara dimulai oleh MC dan dilanjutkan dengan pembacaan doa pembuka. Selanjutnya menyanyikan lagu Indonesia Raya dan Mars Karang Taruna. Pembukaan acara dimulai pada pukul 08.40 WIB.

1. Sambutan

Sambutan pertama disampaikan oleh Ibnu Fajar, SE., selaku Ketua Karang Taruna yang menegaskan dalam sambutannya untuk memajukan kembali kegiatan Karang Taruna dalam kepengurusan baru. Sambutan berikutnya disampaikan oleh Sekretaris Kelurahan Bapak Hasan Azhari, SE., selaku Pembina Karang Taruna Kelurahan. Beliau menjelaskan sejarah pasang surutnya lembaga Karang Taruna Kelurahan Pondok Benda dan ingin kembali meningkatkan kinerjanya kembali. Terakhir sambutan dari Ketua tim PKM dosen Manajemen UNPAM Arif Siaha Widodo S.E.,M.M yang menjelaskan peran dosen terkait Tri Dharma Perguruan Tinggi yang salah satunya melalui Pengabdian Kepada Masyarakat.

Sambutan dari Ketua Karang Taruna, Sekretaris Kelurahan dan
Ketua tim PKM berjalan lancar. Kegiatan ini dimulai pukul 08.58 WIB.

2. Pembahasan Materi dan Diskusi

Pelaksanaan pemaparan materi berupa seminar yang disampaikan oleh empat pemateri atau narasumber tiga diantaranya dari tim dosen PKM UNPAM dan satu anggota dari dewan komisi 1 DPRD Kota Tangerang Selatan yang berkenan hadir dan memberikan informasi dalam kegiatan PKM ini. Pemaparan materi pertama disampaikan oleh anggota dewan komisi 1 DPRD Kota Tangerang Selatan, Bapak Safrudin SH., yang menyampaikan materi terkait peran legislatif dalam mengayomi lembaga kemasyarakatan yang saat ini sedang dibahas dalam Rancangan Peraturan Daerah tentang Lembaga Kemasyarakatan yang salah satunya adalah Karang Taruna. Selanjutnya pemaparan materi inti disampaikan oleh tiga dosen dari tim PKM UNPAM, yaitu Dedek Kumara S.E., M.M., yang menyampaikan materi terkait posisi Karang Taruna dalam Pemda, Ahmad Dimyanti, S.Sos.I., M.Ikom., yang menyampaikan materi terkait reorientasi peran Karang Taruna untuk mengaktifkan kegiatan ke depan, dan Taufik Awaludin S.E., M.Si., yang menyampaikan materi terkait evaluasi peran Karang Taruna. Ketiganya bersinergi memberikan pemaparan terkait dengan pemberdayaan karang taruna melalui pengembangan zona baca, 


\section{JURNAL ABDIMAS

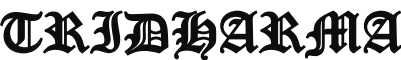 AtA:}

P-ISSN 0000-0000, E-ISSN 0000-0000

Jurnal ABDIMAS Vol. 1,No.1, Agustus 2019, Hal (27-40)

@Prodi Manajemen Fakultas Ekonomi Universitas Pamulang

Email: abdimasjurnal.unpam@gmail.com Telp: (021) 741-2566 motivasi diri pengembangan karakteristik anggota karang taruna, serta terkait fungsi dan karakteristik organisasi dan bagaimana melakukan analisis organisasi untuk evaluasi kinerja organisasi khususnya karang taruna. Kegiatan diakhiri dengan diskusi dari peserta yang mempertanyakan permasalahanpermasalahan riil Karang Taruna di Kelurahan Pondok Benda. Pembahasan materi dan diskusi dilaksanakan di Kantor Kelurahan Pondok Benda Lantai 3, pada pukul 09.30 - 12.45 WIB.

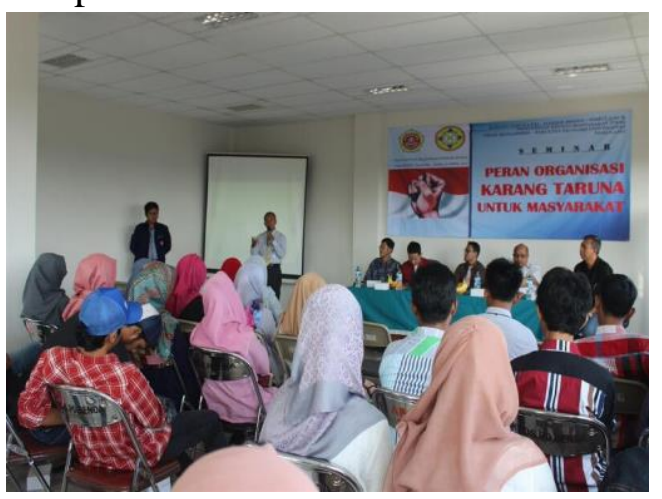

3. Penutupan, Serah Terima Plakat dan Doa Penutup

Setelah acara diskusi selesai dilanjutkan dengan pembacaan doa penutup, yang kemudian dilanjutkan dengan pemberian plakat dan sesi foto bersama, pembagian doorprizesebagai bentuk apresiasi bagi para peserta seminar yang aktif dalam forum diskusi dan datang tepat waktu, kemudian acara di tutup oleh MC. Kegiatan ini selesai dan berjalan lancar pada pukul 13.00 WIB.

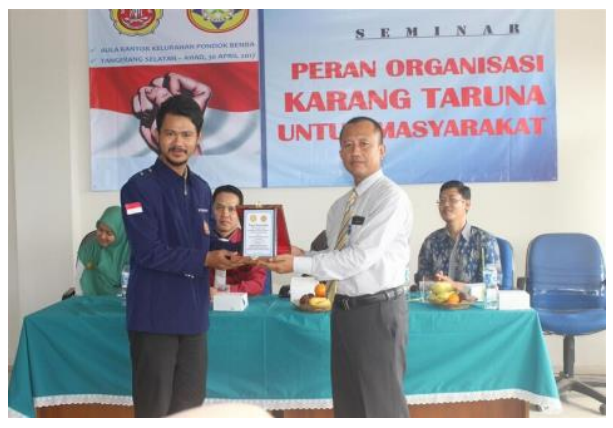

KESIMPULAN DAN SARAN

Kesimpulan

Berdasarkan pelaksanaan kegiatan Pengabdian Kepada Masyarakat yang dilaksanakan di Kelurahan Pondok Benda Kecamatan Pamulang pada hari Ahad 30 April 2017 dapat ditarik kesimpulan bahwa secara umum kegiatan pengabdian kepada masyarakat dapat terlaksana dengan baik dan mendapat sambutan dan dukungan dari pihak Kelurahan Karang Benda dari segi tempat, sarana prasarana dan akomodasi, serta antusias para peserta yaitu pengurus dan anggota Karang Taruna Kelurahan Pondok Benda sehingga dapat terciptanya kesadaran akan pentingnya peran dan kontribusi Karang Taruna dalam memajukan kehidupan masyarakat terutama di lingkungan masyarakat Kelurahan Pondok Benda.

Saran

Berdasarkan kegiatan yang sudah terlaksana beberapa saran yang dapat kami sampaikan untuk kemajuan Karang Taruna Kelurahan Pondok Benda adalah perlunya peningkatan kegiatan dalam Karang Taruna sebagai wadah silaturahmi, pembentukan karakter, potensi wirausaha, serta kegiatan bakti sosial di Lingkungan Kelurahan Pondok Benda, selain itu 


\section{JURNAL ABDIMAS

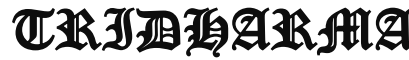

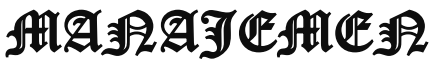

P-ISSN 0000-0000 , E-ISSN 0000-0000

Jurnal ABDIMAS Vol. 1,No.1, Agustus 2019, Hal (27-40)

@Prodi Manajemen Fakultas Ekonomi Universitas Pamulang

Email: abdimasjurnal.unpam@gmail.com Telp: (021) 741-2566 perlunya peningkatan kreativitas pemuda yang ditindaklanjuti dengan menggali kondisi lingkungan sekitar untuk menentukan suatu masalah yang kemudian bisa dipecahkan melalui kegiatan aksi nyata yang bisa menjadi salah satu program kerja kegiatan yang akan dilaksanakan Karang Taruna sehingga dapat ikut berperan dalam pembangunan daerah.

\section{DAFTAR PUSTAKA}

Direktorat Bina Karang Taruna. 2005. Buku Pedoman Dasar Karang Taruna. Departemen Sosial R.I

Handayaningrat, Soewarno, 1985. Pengantar Studi Ilmu Administrasi dan Manajemen. Jakarta : Haji Masagung

Handoko,T.Hani. 2012. Manajemen Personalia dan Sumber Daya Manusia. Edisi Ke-2. Yogyakarta: BPFE.

Hasibuan, S.P.M. 2011. Manajemen Dasar, Pengertian, dan Masalah. CV. Haji Masagung, Jakarta.

L.Mathis., Robert dan John H.Jackson.Manajemen Sumber Daya Manusia. PT.Salemba 4. Jakarta. Edisi 10. 2006

Malayu Hasibuan S. P. 2012. Manajemen Sumber Daya Manusia. Cetekan keenam belas. Jakarta. PT. Bumi Akasara.

Mangkunegara, A.A Anwar Prabu. 2009. Manajemen Sumber Daya Manusia. Bandung: PT. Remaja Rosdakarya.

Mangkunegara,Anwar Prabu. Manajemen Sumber Daya Manusia Perusahaan. PT.Remaja Rosdakarya.
Bandung. Cetakan ke-12. 2013

Marwansyah. Manajemen Sumber Daya Manusia. CV Alfabeta. Bandung. 2010

Stephen P. Robbins. 1994. Teori Organisasi Struktur Design dan Aplikasi. Jakarta. Arcan.

Tim LPPM Pamulang. 2016. Buku Panduan Penelitian dan Pengabdian Kepada Masyarakat. Universitas Pamulang. Tangerang Selatan 